\title{
AN ANALYSIS OF FACTORS INFLUENCING LEARNERS' IN LEARNING LANGUAGE
}

\author{
$1^{\text {st }}$ Franscy \\ English Education Department \\ STKIP Panca Sakti Bekasi, Jawa Barat, Indonesia \\ franscy@panca-sakti.ac.id
}

\author{
$2^{\text {nd }}$ Rezki Puteri Syahrani Nurul Fatimah \\ Indonesia Language and Literature Faculty \\ Universitas Riau, Pekanbaru, Indonesia \\ rezkiputeri@yahoo.co.id
}

\begin{abstract}
The aim of this research is to describe the factors influencing learners' in learning language. This research used qualitative approach. Type of the data in this research is qualitative data that consist by collecting library data, reading, recording and processing library collection materials without need field research. This research presents scientific reasoning arguments from the result of literature review and the researcher' thinking about the problems in learning language. The library materials are discussed critically and deeply in support of discussing the factors influencing learners' in learning language. Research result shows that there are four important factors in education process that have an influence on the process of teaching and learning language, these factors include curriculum factor, institution factor, teacher factor, teaching factor and students factor. From understanding and analysis the theory indicated that in the process of teaching and learning language as effectively category, not only focus on teacher and students factors, but also other factors have relevance and influence with each other, to achieve the learning purpose. Therefore, understanding the role and function of four factors are very important in creating an effectiveness design of learning language for learners. An understanding the creation of effective learning language process is required in order to obtain synergy and perfect preparation of all the important factors above. So, the process learning language in our educational environment will achieve the expected goals.
\end{abstract}

Keywords: learning factors; learners; learning language.

\section{INTRODUCTION}

One of the important aspect in teaching and learning process is the educator or teacher. In this activity certainly the teaching and learning process is not done carelessly, but a good design is needed and makes it can provide changes in student behavior and experience. This is very important because learning is a mental process that occurs within a person, causing a change in behavior. Mental activity occurs because of the interaction of individuals with a conscious environment (Sanjaya, 2009).

In the language learning process a teacher in delivering and explaining learning is not done spontaneously, but it needs a good design so that the learning process can run effectively and efficiently. So the teacher must know and understand what learning design is, and teaching factors that are interrelated with each other.

The design of learning is the operational definition of the curriculum, while the application of the design will be seen in the learning activities. Learning design has a very important role in the teaching and learning process, especially as a projection tool for activities to be carried out during learning. The function of learning design as a guideline or guide for activities that describing the results to be achieved, as a control and evaluation tool. The form of learning design is the learning syllabus and learning implementation plan.

The design of learning can be interpreted as preparation for learning itself. This is based on the assumption that if there is no good learning preparation so the opportunity to be undirected will happen, and may tend to improvise on their own without clear references. Basically, the design of teaching and learning establishes the goal that the teacher wants to produce during learning and how the teacher achieves that goal. Usually, 
the design of teaching and learning is made in written form, but this is not a necessity. Novice teachers may need to make a very detailed learning plan - clearly showing what will happen at each stage of learning.

But in the reality, making a detailed daily learning plan like this is considered to be less practical. Although for teachers who already have a lot of experience and confidence, they still consider that learning design is important. In addition, the ability of teachers to develop designs is growing, so highly experienced teachers or expert teachers can just enter the class with only a small note or even with a lesson plan in their head.

One of the main reasons why making a design is considered important because the teacher needs to identify the objectives of the learning. Teachers need to know what they expect students to do at the end of learning, which students previously could not do. Bruce Weil in Sanjaya (2009, p. 216) show there are three important principles in the learning process:

1. The learning process is forming environmental creations that can shape or change the cognitive structure of students. Cognitive structure will grow where students have learning experience. Therefore, the learning process requires full student activity.

2. Relate to the types of knowledge that must be learned. First knowledge is physical knowledge which is knowledge of the physical properties of an object or event; second, social knowledge is related to individual behavior in a social system or the relationship between humans that can influence social interaction; and third knowledge of logic (mathematical thinking) which is knowledge that is formed based on experience with a particular object and event.

3. In the learning process must involve the role of the social environment. Through children social relations that will be more effective learning compared with learning that distance themselves from social relations.
To implement the tasks well, the teacher needs the ability to plan teaching, write down the teaching objectives, present lesson material, give questions to students, teach concepts, communicate with students, observe classes and evaluate learning outcomes.

Therefore, the design contains a broad set of decisions and an explanation of the objectives, determining policies, determining the program, determining certain methods and procedures and determining activities based on daily schedule. Still related to the design of learning, the main tasks of teachers in this context are: designing learning systems, designing messages, designing learning strategies and designing learner characteristics (Seels and Richey, 1994).

Learning design can be interpreted from various perspectives, for example as a discipline, as a science, as a system, and as a process. As a discipline, learning design discusses various researches and theories about strategies and the process of developing learning and implementation. As a science, learning design is a science for creating specifications for development, implementation, assessment, and management of situations that provide learning service facilities at macro and micro scales for various subjects at various levels of complexity. As a system, learning design is the development of a learning system and its implementation system including facilities and procedures to improve the quality of learning.

Comprehensive design will give a positive impression in the process of student language learning. Through the design of teaching the teacher can determine the time, sequence and emphasis on the contents of each lesson. Through the design of teaching, the teacher can also prepare teaching resources that are appropriate with the content of the lesson and students' interests. But still paying attention and adjusting to what has been set by the Ministry of Education.

In addition, the teacher must know the goals to be achieved in each material to be taught. In this case the design is the beginning 
of all processes of implementing a rational activity. The design according to Sanjaya (2008, p. 77), must have four elements, which include:

1. There are goals that must be achieved

2. There is a strategy to achieve goals

3. Resources that can support

4. Implementation of each decision.

Learning design is a decision-making process that results from rational thinking about objectives and specific learning goals, behavioral changes and a series of activities that must be carried out as an effort to achieve these objectives by utilizing all potential and existing learning resources. The final result of the decision-making process is the compilation of documents that contain the things above, and the next that document can be used as a reference and guideline in carrying out the learning process. Characteristics of Learning Design (Sanjaya, 2008) :

1. Is the result of thought processes.

2. Arranged to change student behavior in accordance with the goals to be achieved.

3. Contains a series of activities that must be carried out to achieve the objectives.

But according to Rohani (1995, p. 43) the references and guidelines in carrying out the learning process must be arranged on the basis of the function of effective learning design involving eight functions, including:

1. Creative Function, with a good design can provide feedback that can describe various weaknesses that occur. Through feedback, teachers can improve and improve the program. Creatively, the teacher will correct various weaknesses and discover new things.

2. Innovative function, an innovation will emerge if you understand the gap between expectations and reality. The gap can be caught if you understand the process carried out systematically. This systematic learning process is planned and programmed in its entirety.

3. Selective functions, with the design process we can select which strategies are considered more effective and efficient to develop. This selective function is related to the selection of learning material that is considered appropriate to the learning objectives.

4. Communicative function, an adequate design must be able to explain to everyone involved, both to the teacher, to students, the principal even to external parties such as parents and the community. The design document must be able to communicate to everyone both about the objectives and the results to be achieved.

5. Predictive functions, designs can describe various difficulties that will occur and can describe the results to be obtained.

6. Accuracy function, with the design of the teacher can measure every time needed to deliver learning material, the teacher can determine the effective lesson hours.

7. The function of achieving goals, learning has two equally important sides, namely the learning outcomes and the learning process. Through the design, both sides of learning can be carried out in a balanced manner.

8. Control function, can determine the extent to which the subject matter can be absorbed by students, which material has been and has not been understood by students. Design as a control can provide feedback to the teacher to develop the next learning program.

\section{METHOD}

This reseach used qualitative approach by emphasizing its analysis on the process of inferring comparison and also the correlation dynamics of the observed phenomena using 
scientific logic (Azmar, 2001). The method of this research is library research with a series of activities relating to the collecting library data, reading, recording and processing library collection materials without need field research (Mestika, 2004). There are two reasons that underlie researchers to use library research; first, literature research is needed as one of the prelimenry research stages to understand more about new symptoms that are developing in the field or in society; second, library data remains reliable to answer the problems in this research.

This research presents scientific reasoning arguments from the result of literature review and the researchers' thinking about the problems in learning language. This research is supported by data obtained from library sources like research journals, textbooks, papers, scientific discussions and others. These library materials are discussed critically and deeply in support of discussing the factors influencing learners' in learning language.

\section{RESULT AND DISCUSSION}

Learning process especially language learning is a complex learning and not simple process. The process of language learning requires careful thinking that is not only focused on educators, but other factors such as curriculum and institutions also have important influences in a learning design to achieve effective learning goals.

\section{Curriculum Factors}

Understanding the curriculum broadly is not only in the form of subjects or fields of study and student learning activities, but also everything that affects the formation of personal students in accordance with the expected educational goals. For example, school facilities, a safe environment, and an atmosphere of intimacy in the teaching and learning process, media and adequate learning resources. Things that must exist in the design of the curriculum, likes: a) the existence of goals that must be achieved, b) the existence of a strategy to achieve goals, c) resources that can support, and d) implementation of each decision.

Curriculum is also a document that contains the learning design that is arranged as a teacher's guide in carrying out the learning process. A design must be realized to see whether the design is successful in achieving the goal as expected or not. The implementation of the curriculum is a learning process. So, the curriculum and learning process cannot be separated because it is a unit of influence. Curriculum without learning will not be effective and the curriculum without the learning process is only a document without meaningful.

\section{a. Learning-centered design}

1) Design based on activities / experience

The first characteristic of this design is the existence of transactions between instructors and learners in mapping the interests and needs of learners especially in language learning. The teacher's role in this connection is to develop abilities that are in line with learners' interests and needs and develop in the form of curriculum. So that this curriculum is designed according to the activities or experiences.

2) Humanistic design

This design is almost the same as experience-based design which emphasizes the individual needs of language learners in a more conducive and supportive environment. Humanistic design aims to equip learners with experiences that are intrinsically beneficial for learners' selfdevelopment, among others, to strengthen self-concepts through the creation of supportive learning experiences.

\section{b. Problem-Centered Designs}

1) Thematic Design

Curriculum has to provide learning experiences that reflect real life which is meaningful and useful 
for learners. For this reason, the various themes faced in the lives of individual learners and communities both in local, regional and global contexts must be included in the curriculum. Therefore, themes can be taken from the closest environment to the learner and various fields of study that have relevance to the reality faced by the learner. If the theme taken from the field of study is usually integrated.

2) Design based on the Problem

This design moves from the view that learners must be faced with real life problems in order to understand their world. As with thematic design, this design emphasizes meaningfulness as a basis for curriculum design so that what is covered in the curriculum is seen as relevant. The difference with thematic design consist in identifying, handling, and solving various problems. Through this process, learners will gain meaningful learning experiences and can play more roles in society. Therefore, this design emphasizes solving problems that are relevant to the real life faced by learners and their society.

\section{Institution Factors}

There are several factors that play an important role in improving the quality of an educational institution, broadly covering three factors which include management of the organizational structure, the design strategy of the institution program, and the development program for the teacher and the teaching context.

\section{a. Organizational Management}

Organizational structure management in an institution such as a school has an important role in creating an effective learning process, because with the existence of a good organizational structure management, the school will succeed in achieving educational goals and objectives. There are two types of organizational structure designs commonly found in educational institutions, namely mechanistic models and organic models. The mechanistic model is a mechanistic bureaucratic approach to organizing collective activities that emphasize the need for authority, the hierarchy of control, and the chain of explicit command. While the organic model is one that maximizes flexibility and adaptability, encourages confidence and trust between superiors and subordinates, and channel various motivations from humans to achieve goals (Davidson and Tesh in Richards, 2001). Through these two models the school can implement an organizational structure design that is appropriate to apply, another important aspect that plays a role in the organizational structure is the leadership of institutions / institutions.

\section{b. Institutional Program Design}

Educational institutions in providing educational services to students must have a strategic plan that can be used as a guideline for running educational programs that are structured so that they can run well. The strategy plan is interpreted as a description of the long-term vision and objectives of the institution, and a tool that is responsible for fulfilling the programs in the part of the plan (Richards, 2001). Klinghammer in Richards (2001, p. 203) provides an overview of a strategic plan that is good for an institution or institution consisting of six elements including:

1) Vision: statements that provide a long-term description of the program and what expectations can be achieved.

2) Value: principles that will guide the implementation of the program, in terms of responsibilities to students, teachers, and others.

3) Purpose: the basic reason for the existence of the institution.

4) Mission: description of the institution's vision in terms of certain goals that are trying to be achieved, usually within a certain 
period of time. This is expressed in the form of a mission statement.

5) Goals: specific steps related to each aspect of the mission, such as increasing student enrollment, developing teaching materials, or providing an environment where teachers can conduct classroom research.

6) Strategies: strategies and activities that will be used to achieve the objectives.

\section{c. Development Program for Teachers and Teaching Contexts.}

Efforts to improve the quality of education in schools must be accompanied by efforts to improve professional abilities and improve the quality of the personality of the teacher. Among other things by providing as many opportunities as possible for teachers to participate in programs related to improving their abilities in the field of language, such as:
1) Conference participation
2) Workshops and in-service seminars
3) Reading groups
4) Peer observation
5) Writing about teaching
6) Project work
7) Action research (Richards, 2001)

Besides the professional development of a teacher, there is still one last factor that has an important effect on the success of teaching in an institution / school institution which is about a good teaching context, which consists of several aspects such as:

1) Size and Staff Structure

The size and structure of staff is very influential in the teaching process of the teacher, where when a large number and structure of staff will lead to inefficiencies in the process of interacting. So it needs the role of institutions to facilitate teachers to get to know each other and to develop a sense of collegiality.

2) Equipment

In the teaching process, some tools need to be needed that can support the learning process to the maximum, such as computers, cassette and CD players, vidieo recorders etc. Where the equipment is prepared by educational institutions.

3) Support Staff

Adequate support staff will facilitate the work of a teacher, such as secretary staff who help to type, duplicate files, etc.

4) Teacher Work Space

Placement of work space can also be influential because it is in this room that teachers can interact with other teachers, prepare teaching materials and make assignments.

5) Teacher Resource Room

A teacher needs this room because through this room the teacher can renew new knowledge and ideas in teaching.

6) Teaching Facilities

In addition to classroom facilities, in the learning process other supporting facilities are needed in the form of a lab. mulimedia or computer, lab. Language, selfdevelopment center and student reading room.

7) Class Size

Placement of the number of students in a room also has an influence in the delivery or learning process because if there are a large number of students in one room, the ignition of the metar will not be accepted maximally differently if the students in one room are few in number.

\section{Teacher Factors}

The teacher as the important aspect in the implementation of education is a very influential party in the teaching and learning process, particularly in the teaching of language. Teacher's expertise and authority greatly determines the continuity of the teaching and learning process in the classroom and its effects outside the 
classroom. The teacher must be smart to bring students to the goals to be achieved.

\section{a. The ability or skill that can shape the} authority of the teacher are:

1) The level of mastery of linguistic material and scientific concepts.

2) Methods, approaches, or teaching styles that are appropriate to the situation and conditions of students.

3) Be able to establish good relations between individuals, both with students and among fellow teachers and other elements involved in the education process such as administrators, like a principal, administration and the surrounding community.

\section{b. Core Components for a Teacher in the Teaching and Learning Process}

1) Practical Knowledge: teacher techniques in the classroom and strategies

2) Content Knowledge: teacher's understanding of the subject matter to be taught.

3) Contextual Knowledge: understanding or being close to institutions, school norms and knowledge of students.

4) Pedagogical Knowledge: the ability to restructure knowledge content for teaching purposes.

5) Personal Knowledge: principles and individual approaches to teaching.

6) Reflective Knowledge: the teacher's capacity to reflect and judge for himself (Richards, 2001).

\section{c. Teacher Skills in Implementing Effective Learning Processes}

1) Make observations to experienced teachers.

2) Make observations through the training video.

3) Take a short theoretical course.

4) Doing exercises under the supervision of experienced teachers.

5) Working together with teacher mentors (Richards, 2001, p. 211).
Therefore, in creating an effective educational process, teacher involvement from the design of educational innovations to implementation and evaluation plays a very large role for the success of better educational innovations.

\section{Teaching Factors}

Teaching factors according to Brown (1995, p. 179) are part of an effective teaching design with several related factors such as need to involve teachers in the curriculum, teacher support, providing a set of support, monitoring teachers, and revitalizing teachers.

\section{a. Involving Teachers in the Curriculum}

Teacher involvement is very necessary to contribute curriculum development, so the development is very comprehensive based on teacher experiences during teaching, including in providing input in language teaching that have different levels of difficulty in each place. The teacher carries out three approaches to children as curriculum sources, including student needs, student development and student interest. All student needs are definitely well known by the teacher as teaching instructors in the classroom. In Caswell's curriculum development (Sukmadinata, 1988) emphasizes the participation of teachers, participating in determining the curriculum, determining the organizational structure of curriculum development, formulating objectives and assessing results.

\section{b. Teacher Support}

The role of teacher support in the curriculum requires a real work process, because this is one of the determinants of the success learning process. The forms of teacher support include:

1) Needs Analysis

2) Receiving Student Input

3) Motivator

4) Student Organizers and Behavior Controllers

5) Demonstrator to show the correct use of language

6) Material Developers 
7) Monitor Student Learning

8) Counselors and Friends

\section{c. The Teacher Monitor}

Regularly scheduled monitoring, as part of the curriculum can help teachers as individuals to think about what is good at teaching to improve their performance. Activities in monitoring the teacher such as:

1) Observing the class, where the teacher is observed during the learning process.

2) Administrative Observations, are teacher administrative observations such as teaching documentation (Syllabus, RPP), student grades (report cards, tests, and assignments), students' guidebook to measuring student progress (Communication between Teachers and Student Parents).

3) Observation with Workers, is another effective resource to help monitor teachers with contribute to the professional development of the two teachers as observers.

4) Self-Observation, another effective alternative to the practice of class observation is making observations through a video camera.

\section{d. Revitalization of Teachers}

Teachers are also living things who breathe and need creative space. Teachers are also humans who often find problems that can interfere with their work. In this case it is necessary to make provisions for the teachers if they have stress continously, they still feel optimistic and positive in learning and teaching activities. This problem cannot be underestimated, so a teacher must improve his professional capacity in carrying out each component of the curriculum, therefore a teacher must continue to improve and continue to develop.

\section{Student Factors}

\section{a. Language Learning Experience}

Students' learning experience also influence the level of students' cognitive to understanding based on previous student learning experiences. Sometimes students master language lessons quickly because they have learned the elements of language learning before. Like taking courses or additional lessons. So that students can understand language comprehension comprehensively.

\section{b. Motivation}

Students who are strongly motivated must succeed because students have more encouragement to not only pass the exam but also to develop themselves in the future. Some things can be attempted to arouse learning motivation in students: the selection of teaching materials that are meaningful to students, creates learning activities that can generate an urge to find (discovery), translate what will be taught in a form that is appropriate to the level of student development.

\section{c. Diversity Level of Students in the Classroom}

The diversity factor of students in the class also greatly influences teaching. If the language skills are too diverse, the teacher will find it difficult to continue the next stage of teaching. Therefore the solution of this is to do a Placement Test and Aptitude Test to make students' abilities are conditioned equally so that teaching can be maximized.

\section{CONCLUSION}

The design of teaching and learning language is the operational definition of the curriculum, while the application of the design is seen in the learning activities. The function of learning design is as a guideline or guide to activities that describe the results achieved, can be interpreted as a control and evaluation tool. The factors influencing learners' in learning language is strongly influenced by several factors, including; 1) curriculum and component factors, 2) institutional factors, 3) teacher factors, 4) teaching factors, and 5) student factors.

The curriculum is not only in the form of subjects and student learning activities, but also everything that affects in the expected educational goals. To obtain good quality of 
education, besides the students have to have sufficient potential to complete the learning program demanded by the curriculum, institutions such as schools have to provide good services program for students. Moreover, the teacher as a very influential party in the teaching and learning process, the teacher's expertise and authority determines the continuity of the teaching and learning process in the classroom and its effects outside the classroom. Understanding the creation of effective learning design in the process of teaching and learning of language requires the synergy and preparatory of several factors above. Thus, the process of teaching and learning in our educational environment will achieve the expected goals.

\section{REFERENCES}

Azmar, S. (2001). Metode Penelitian. Yogyakarta: Pustaka Pelajar.

Brown, J. D. (1995). The Elements of Language Curriculum. Boston: Heinle \& Heinle.

Mestika, Z. (2004). Metode Penelitian Kepus takaan. Jakarta: Yayasan bogor Ind onesia.

Richard, J. C. (2001). Curriculum Developm ent in Language Teaching. Cambrid ge: Cambridge University Press.

Rohani, A. (1995). Pengelolaan Pengajaran. Jakarta: Rineka Cipta.

Seels, B. B. and Richey, R. C. (1994). Teknologi Pembelajaran: Definisi dan Kawasannya. Terjemahan. Jakarta: IPTPI Miarso.

Sukmadinata, N. S. (1988). Prinsip dan Landasan Pengembangan Kurikulum. Jakarta: Depdikbud.

Sanjaya, W. (2008). Rancangan dan Desain Sistem Pembelajaran. Jakarta: Kencana Prenada Media Group. 